\title{
A representação da alteridade: estereótipos do índio brasileiro no cinema de ficção da década de 70 *
}

Rosa Berardo**

\begin{abstract}
Resumo
O objetivo deste artigo é analisar as várias maneiras utilizadas pelos diretores brasileiros para representar os índios brasileiros na década de 70 . As análises aqui apresentadas baseiam-se em dados histórico-políticos e análise fílmica.

Um dos pontos questionados neste trabalho é como a política cultural do Estado na época influenciou os diretores em suas representações e também como os estereótipos são criados por meio das imagens, criando preconceitos ou imagens positivas dos índios.

A representação ou fabricação do outro nunca é neutra, devido às próprias fantasias, excessos, projeções, ideologias e interesses políticos dos diretores dos filmes.

Palavras-chave: filme brasileiro, índios, representação.
\end{abstract}

A representação do índio brasileiro nos suportes iconográficos, literários, fotográficos e cinematográficos, desde o descobrimento do Brasil até a atualidade, incorre, algumas vezes, nos mesmos erros: idealizações da imagem do outro ou reprodução de estereótipos.

Num breve retrospecto da representação do índio nos diários de viagem dos primeiros navegadores ou nos documentos dos pintoresetnógrafos e cronistas viajantes, podem ser detectados sérios problemas de ordem etnográfica na representação da alteridade e na construção da identidade do grupo representado. Os estudos realizados

* Artigo extraído da tese de doutorado da autora, apresentada na Université de la Sorbonne Nouvelle, em Junho de 2000.

** Dra. em Cinema pela Sorbonne, Paris III e professora do Mestrado em Cultura Visual da UFG.

Comun. Inf., v. 5, n. 1/2, p.63-75, jan./dez. 2002 
por antropólogos e historiadores registraram o quanto o imaginário pessoal, político e religioso daquele que descrevia o outro influenciou a elaboração de imagens físicas e comportamentais falsas, carregadas de ideologia. A generalização dos tipos físicos, hábitos culturais e valores específicos de cada etnia indígena repete-se em vários documentos históricos. O índio brasileiro tornou-se uma entidade genérica, um ser imaginário que povoava o inconsciente europeu segundo conceitos extremos, ou seja, tanto como habitantes de um paraíso perdido quanto como selvagens antropófagos, seres quase que demoníacos, de acordo com a ótica cristã ocidental.

Se esses relatos já foram profundamente estudados como acervo histórico documental do século XVI até hoje, o que dizer então da representação recente da imagem do índio no cinema brasileiro da década de 1970, por diretores também brasileiros? Até que ponto os mesmos estereótipos construídos há quatro séculos têm sua continuidade e reprodução garantida por meio de um suporte próprio desta época, o cinema? Como os códigos específicos da linguagem cinematográfica e as limitações físicas desse suporte reproduzem as imagens dos índios? É o índio cinematográfico também um índio genérico, como o descrito desde 1500 ? Os cineastas tiveram preocupação e habilidade para lidar com os estereótipos?

Tentando responder a algumas dessas questões faremos uma pequena análise de alguns filmes brasileiros da década de 70 que trazem o índio como temática principal.

O filme Iracema, a virgem dos lábios de mel, de Carlos Coimbra, revela, desde o primeiro plano do filme, qual o ponto de vista ideológico do diretor em relação ao índio, que persistirá durante toda a diegese. Se observarmos o primeiro plano da primeira sequiência, vemos que a câmera inicia a tomada no céu e desce num movimento de panorâmica vertical até o personagem Martins, um português, que está numa jangada na costa brasileira. A seguir, a câmera toma o ponto de vista de Martins, que por meio de um olhar subjetivo mostra a praia, que é o território brasileiro, visto de sua jangada. O posicionamento da câmera em relação ao personagem Martins e à terra de Iracema, que é enquadrada do mar em direção à praia, revela o olhar exógeno que predominará durante toda a narrativa cinematográfica. Os índios Tabajara e, em especial, a personagem Iracema são vistos por alguém externo, fora de seu grupo, um olhar personalizado por um europeu. É um ponto de vista de fora para dentro. Esse movimento inicial de câmera,

Comun. Inf., v. 5, n. 1/2, p.63-75, jan./dez. 2002 
a pan de cima para baixo, ao enquadrar o céu e num deslocamento seqüencial chegar até ao personagem Martins, executa em nível simbólico uma associação entre esse personagem e o local de onde partiu o movimento de câmera. Pode-se dizer que revela a intenção do diretor em associar a figura de Martins a uma entidade superior, que veio dos céus e desceu nas terras indígenas. Nesse sentido, a narrativa cinematográfica visa construir a figura heróica do branco (o salvador) em relação ao índio.

No plano seguinte, a câmera mostra imagens da praia, paisagens e detalhes do português que maneja a jangada. Na praia, um índio faz sinal para Martins.

Ainda sob o ponto de vista de fora para dentro, a câmera inicia uma série de pan horizontais, à direita e à esquerda, descrevendo paisagens naturais da terra de Iracema, enquanto uma voz off introduz o espectador num universo idílico da musa de Martins, personagem principal desses filmes de gênero erótico-romântico: "Além, muito além daquela serra que ainda azula no horizonte nasceu Iracema, a virgem dos lábios de mel. Seus cabelos eram mais negros que a asa da graúna e mais longos que os talhes da Palmeira".

O filme é baseado na obra de José de Alencar, que traz em seus livros um índio idealizado, em nada representado em suas particularidades específicas, e sim como uma projeção do imaginário europeu. Carlos Coimbra, sem questionar essa representação idílica do índio, entra por um caminho de reprodução de estereótipos que remontam às primeiras representações produzidas desde os primeiros séculos da descoberta do "novo mundo". Neste caso específico, há a busca da ordem do mundo natural, em que os habitantes das florestas tropicais são considerados como uma extensão da própria natureza, retratada pela estética do romantismo novecentista como pródiga e harmoniosa. Aqui, os cabelos de Iracema são mais negros que as asas de um pássaro e mais longos que as folhas das palmeiras. Iracema se mistura à natureza, perde suas características humanas e se confunde com árvores e aves.

O corpo de Iracema no filme é construído com a intencionalidade erótico-sensual. A importância etnográfica da caracterização de um personagem que traz em seu corpo os adornos, a plumária e o grafismo próprios de seu grupo étnico, elementos que o distinguem de outros grupos indígenas, é desprezada por Carlos Coimbra, bem como por todos os outros cineastas dessa década que retrataram os índios bra-

Comun. Inf., v. 5, n. 1/2, p.63-75, jan./dez. 2002 
sileiros em seus filmes. Ao negarem a importância da construção da corporalidade nos personagens indígenas, os cineastas reproduzem os mesmos erros dos pintores etnógrafos e constroem uma idéia genérica sobre o índio brasileiro. Como colocam Vidal e Muller:

\begin{abstract}
“A linguagem simbólica da ornamentação corporal exprime, principalmente, a concepção tribal da pessoa humana, na ordem social e cósmica. A dualidade do corpo e da pintura atua, portanto, como mostrou Lévi-Strauss, para expressar uma realidade da qual o indivíduo participa, projetando-se graficamente na sociedade através da pintura, que o reveste como uma pele social" (apud. ALEGRE, 1994:71).
\end{abstract}

Uma vez que os cineastas, baseados em dados sociais, especificam a etnia ou o grupo representado em sua ficção, há a necessidade de o diretor do filme fazer uma pesquisa histórica e antropológica, para que não haja descaracterização ou ridicularização da identidade do retrato. A noção de pessoa, por meio da corporalidade, constitui um elemento central da construção da identidade nas sociedades indígenas brasileiras como idioma simbólico focal.

Nos filmes Uirá, de Gustavo Dahl; O Guarani, de Fauze Mansur; Como era gostoso o meu francês, de Nelson Pereira dos Santos; e Iracema, de Carlos Coimbra, as etnias indígenas são especificadas com base em dados históricos, mas a representação corporal delas é genérica. No filme Iracema, por exemplo, as genitálias dos índios são encobertas com tangas e tecidos desfiados que descem pelas pernas (como o personagem Irapuã), vestimenta típica de índios norte-americanos. O corte de cabelo e os adornos também lembram uma caracterização dos índios dos Estados Unidos, sem parâmetros com os índios brasileiros. No plano 36 da sequência 4, Araquém, pai de Iracema, recebe Martins em sua taba. Araquém está com os cabelos amarrados de uma forma imprópria aos costumes das etnias indígenas brasileiras. Esse personagem é colocado também fumando o cachimbo da paz, objeto que não é utilizado pelos índios brasileiros, mas que faz parte dos clichês dos westerns norte-americanos, nos quais pistoleiros brancos entram nas aldeias para fumar o cachimbo da paz com o chefe e colocar fim aos conflitos.

Nenhum dos índios que aparecem em cena nesse filme tem uma iconografia corporal, mesmo nas cenas de guerras, momento em que os membros dos grupos pintam os corpos num ritual preparatório para

Comun. Inf., v. 5, n. 1/2, p.63-75, jan./dez. 2002 
a batalha. A pintura reafirma a identidade do grupo. Nos planos $15 \mathrm{e}$ 16 da sequência 03 , Iracema sai da cachoeira e atira uma flecha em Martins. Nos grupos indígenas, as mulheres nunca manuseiam flechas, que são utilizadas apenas pelos homens. Esses dados foram desprezados pelo diretor, talvez por não ter feito uma pesquisa etnográfica para elaborar o roteiro. O filme tenta passar a imagem de índio que o público está acostumado a ver nas produções norte-americanas que sempre invadiram o mercado brasileiro, numa generalização "universal" da figura indígena. As diferenças culturais são desprezadas e não apenas entre as diferentes etnias das comunidades indígenas brasileiras, mas também em nível internacional, como se Apaches e Sioux norte-americanos, aborígenes australianos e Botocudos brasileiros fossem clonados em série.

No filme $O$ Guarani, Peri é representado como um cavalheiro europeu que se comporta segundo as normas burguesas de educação. As reações do índio como portador de uma cultura com valores próprios e forma de comportamento específico foram anuladas para compor o personagem cordial e gentil, segundo o ponto de vista burguês, num enaltecimento próprio da exacerbação da figura do bom selvagem. Esse filme, de Fauze Mansur, é também baseado no romance de José de Alencar, seguindo a mesma linha romântica de Iracema. O ponto de vista do filme em relação ao índio é totalmente eurocêntrico. Peri é servil à aristocrática família de Ceci. Ele protege não apenas sua amada, como também sua família.

A figura heróica de Peri retoma os estereótipos sobre o índio e sua harmonia com a natureza. Fauze Mansur mantém o enfoque dado por José de Alencar, trabalhando a relação índio-colonizador de uma maneira não histórica, como se o encontro cultural desses dois povos distintos passasse pelo crivo da paixão, e não da dizimação cultural indígena. A paixão, ainda que utilizada como elemento para romper fronteiras antropológicas, reproduz a relação de domínio de uma etnia sobre a outra, pois o personagem Peri é subserviente e indigno do amor de Ceci por ser índio. Ele presta serviços de guarda-costas a ela e à sua família. Tem-se, no filme, uma representação da ideologia colonizadora que, necessitada de mão-de-obra escrava indígena para o incremento de suas atividades agropastoris, representa um índio adaptado ao papel servil que lhe oferecem. Justifica-se, assim, as capturas e forja-se uma falsa adaptabilidade de indígenas como força de trabalho não remunerada para os colonizadores ${ }^{1}$. Como Iracema, Peri abre

Comun. Inf., v. 5, n. 1/2, p.63-75, jan./dez. 2002 
mão de seus valores para satisfazer os caprichos do branco colonizador, tudo em nome do "amor". Na sequência 11, para agradar Ceci, que denomina de "minha senhora", Peri caça e lhe traz uma onça viva. O fato de não matar a onça denota uma atitude "ecologicamente correta", já enaltecida pelos europeus seiscentistas e atribui ao índio uma capacidade heróica ou o sonho de total domínio sobre a natureza.

O filme de Mansur tem uma linguagem convencional clássica, pouco inventiva. A linha do romance e da sedução está pautada pelo amor proibido entre o casal Ceci e Peri. A sedução e a virilidade de Peri são apresentadas mediante a força e a postura do modelo de homem europeu, que protege a mulher dos perigos e a poupa das experiências nas quais poderia exercitar sua capacidade de autoproteção e de autonomia. Esse estereótipo de debilidade atribuído às mulheres vem justificar os padrões comportamentais machistas ocidentais, segundo os quais a mulher sempre deveria se submeter à força e à vontade masculinas.

Peri, nesse filme, e Caubé, em Iracema, são exemplos de bons selvagens, que acolhem os brancos defendendo-os de perigos ou ameaças. Seriam guardas-costa, cães de guarda de um chefe superior, prontos a perderem a própria vida para salvar um europeu. Esse exagero de cordialidade vem compor o que se chama de "imagem positiva" (STAM e SHOHAT,1992: 70), ou seja, outra maneira estereotipada de representar o índio no cinema. Caubé está ao lado de seu amigo europeu Martins e o defende de Irapuã, que é também um Tabajara.

Já o índio Irapuã, no filme Iracema, é caracterizado como o "mau selvagem", e sua recusa a Martins é explicada apenas pelo ciúme que tem de Iracema. Seu personagem é construído de maneira a representálo como a força do mal que quer impedir a união do casal, que simboliza a fusão de dois mundos distintos: o europeu e o indígena. Irapuã se opõe e conclama seus guerreiros Tabajaras a lutarem contra a colonização branca (plano 59 da sequiência 07):

Irapuã - Valentes guerreiros Tabajaras, os Potiguaras, nossos inimigos, permitem que venha pelo mar a raça branca dos guerreiros de fogo. Não levará muito tempo e eles estarão invadindo nossos campos. E nós seremos como a pomba que encolhe no ninho quando a serpente vem chegando enroscada no galho?

Todos os índios - Não!

Comun. Inf., v. 5, n. 1/2, p.63-75, jan./dez. 2002 
Irapuã - Os Tabajaras são iguais ao gavião. Quando levanta vôo, ele cai das nuvens e rasga as entranhas do inimigo.

Essa situação de conflito causada pela ameaça da chegada dos brancos é reforçada pela trilha sonora, que utiliza cantos de guerra como fundo musical da cena com a fala de Irapuã, nos planos 66 e 67, aumentando a tensão e atribuindo-lhe a autoria do futuro combate. As cenas de guerra entre os nativos se multiplicam nos primeiros relatos de viagem publicados na Europa a partir do séc. XVI (RAMINELLI, 1996).

Irapuã prevê as consequências da aproximação dos europeus, que culminaria na dizimação indígena. A sequência 9 tem como locação a beira do rio Jaguaribe. Nesse local, Irapuã encontra Iracema deitada ao lado de Martins, que delira sob o efeito do chá alucinógeno que Iracema lhe havia dado. Iracema protege Martins de Irapuã e este promete matar e beber todo o sangue do estrangeiro. Irapuã acredita que quando o sangue de Martins correr pelo seu corpo, Iracema lhe dará o seu amor. O local da locação possui uma forte carga simbólica no que diz respeito ao confronto de culturas, uma vez que a beira do rio é um lugar limite entre o interior da mata (mundo selvagem) e o canal através do qual chega a civilização, ou seja, os portugueses. A beira do rio é uma espécie de lugar onde se confrontam duas culturas. A margem do rio Jaguaribe torna-se um espaço alegórico, entendido como espaço liminar, ou seja, "espaço de enunciação, onde cruzamse constantemente fronteiras culturais, territorialidades distintas" (ARANTES,1994: 197).

Ainda nesse local são rodadas as cenas que mostram a luta pela manutenção das identidades indígenas. A disputa por Iracema é também a luta pelo não-esfacelamento do grupo, causado pela chegada do estrangeiro. É nesse momento que Irapuã verbaliza suas intenções antropofágicas de beber o sangue do inimigo para apoderar-se dos encantos que seduziram Iracema. Durante toda a diegese, ele tenta impedir essa fusão cultural ${ }^{2}$ entre grupos indígenas e europeus, que significa o início da aculturação e perda da identidade indígena. Mas a luta de Irapuã é colocada como animalesca, canibal, selvagem, com cenas apelativas, nas quais ele é caracterizado como um homem forte e malvado que quer tomar e matar o bebê de uma frágil mãe. Tal representação não escapa às reproduções imagéticas dos índios no século XVI feitas por Delaune (RAMINELLI:1996). Irapuã é construído

Comun. Inf., v. 5, n. 1/2, p.63-75, jan./dez. 2002 
como um personagem "bárbaro" pelo diretor Carlos Coimbra, que perpetua, assim, estereótipos seculares.

Na sequência 10, Caubé, um personagem 'bom selvagem', irmão de Iracema, coloca-se ao lado de Martins como seu defensor e a favor da união deste com sua irmã, aumentando as divergências entre os grupos indígenas.

Na sequência 14, Martins parte com Caubé, a pedido de Araquém, e se despede de Iracema com um beijo na boca. Iracema se assusta ao concretizar a transgressão cultural em relação a seu grupo. Ela o olha partir quase chorando. Um papagaio vem pousar em seus ombros. A união de portugueses e índios se dá aqui de maneira romântica e natural, o que não aconteceu históricamente. Esse romantismo, mais uma vez, vem camuflar a verdadeira história genocida sofrida pelos povos autóctones, vítimas de morte e escravidão.

Nesse jogo entre bom e mau, criado na narrativa, o índio Irapuã é tido como vilão, e Martins fica enaltecido como o herói branco, incorporando a figura do europeu que veio com "boas intenções". Em vez de aculturar os índios, ele acultura-se falando a língua deles, guerreando, pintando o corpo e dançando. Torna-se pai de uma criança índia e constrói uma casa de coqueiro à beira da praia, território limite entre o nacional e o estrangeiro, lugar onde aportam os que chegam de fora. Essa estratégia de aproximação e infiltração cultural é mais eficaz e menos criticada que invasões colonizadoras extrativistas e arrebanhamento de mão-de-obra escrava.

Retomando as críticas à inversão de valores adotada pelo diretor de Iracema , no plano 23 da sequência 03, após ser ferido pela flecha, Martins conversa amistosamente com a índia, reproduzindo a figura do bom e cordial colonizador, sem as ambições que tomavam conta dos navegadores da época, como a busca do ouro e do pau-brasil. As representações de Martins e Iracema os tornam seres idealizados. Iracema, em nome do amor, é capaz de romper com as tradições indígenas Tabajaras e entregar-se a Martins que, simbolicamente, ao apossar-se da mulher "sagrada", Iracema, apossa-se também do território indígena, fincando alí suas características culturais, minando um campo estrangeiro física e culturalmente.

De uma maneira fortemente ideológica, os estereótipos e as imagens positivas são camuflados por uma situação romântica. Os conflitos e as diferenças culturais são desconsiderados, como se a relação entre colonizadores e gentios houvesse acontecido nos moldes dessa

Comun. Inf., v. 5, n. 1/2, p.63-75, jan./dez. 2002 
narrativa cinematográfica, sem que a história desse conta da morte de 5 milhões de índios brasileiros desde a época da colonização até o presente. Um exemplo de como o diretor estrutura o discurso cinematográfico a esse respeito pode ser encontrado na sequência 03 , do plano 24 ao 35, no diálogo entre Iracema e Martins:

Martins - Venho de longe, do outro lado do mar. A linguagem aprendi com o guerreiro Poti, que eu considero meu irmão.

Iracema - Poti é nosso inimigo. Tu também é nosso inimigo Martins - Já vivi muitas guerras, agora apenas desejo a paz. Se Poti é inimigo de seu povo, que haja paz entre seu povo e Poti

Iracema - Se você diz a verdade, bem-vindo seja aos campos Tabajaras e à tenda de Araquém, pai de Iracema.

Apesar de identificá-lo como inimigo pela sua ligação com os Potiguaras, Iracema ingenuamente acredita em seu discurso e logo lhe dá boas-vindas, convidando-o à cabana de seu pai, que é o chefe. Nesse sentido, desconsidera os problemas e as diferenças culturais entre as três etnias envolvidas no conflito: Tabajara, Potiguara e europeus. O colonizador idealizado não aportou, aqui, com intenções lucrativas, veio trazer a paz entre as nações indígenas autóctones, como um pacificador de bárbaros. A idéia de paraíso perdido e do selvagem como protetor da floresta, muito difundida no século XII (RAMINELLI,1996), é também retomada nessa fase do romantismo de José de Alencar, na literatura, e por Carlos Coimbra, no cinema.

A idealização de uma cena sem conflitos, onde homem e natureza estejam em harmonia, é construída durante a narrativa do plano 55 da sequência 05, à beira do rio e na mata. A locação é feita num cenário bucólico, com vários indígenas adultos e crianças tomando banho no rio Jaguaribe, todos em comunhão com a natureza. Tal representação, na qual os índios se encontram muito envolvidos pela mata, pelo rio, é comum nos registros pictóricos dos primeiros pintores que visitavam o Brasil. Os desenhos de Eckhout sobre os Tupis e os Tapuias remetem a essa cena cinematográfica. Segundo Raminelli (1996:87):

"A vegetação em torno do índio reforça este simbolismo, pois não possui vínculo de subserviência aos europeus. Os arbustos, folhas e as pequenas frutas constituem uma natureza selvagem, imprópria aos anseios do capital".

Comun. Inf., v. 5, n. 1/2, p.63-75, jan./dez. 2002 
De maneira explícita ou alegórica, as situações cinematográficas apresentadas no filme Iracema trazem o peso ideológico da filosofia cristã colonizadora, que tinha nos relatos de viajantes, como Jean de Léry, um reforço à imagem demoníaca do inferno americano habitado pelos indígenas. Nesse local imaginário, as lutas entre o bem e o mal davam-se entre índios e europeus, bons e maus selvagens, observados por ilustres colonizadores.

A imagem do colonizador é poupada de críticas e referências negativas. Nos relatos dos viajantes e nas gravuras dos artistas, o europeu é sempre uma vítima dos índios ou um apaziguador de guerras e salvador de almas. Em Iracema, o personagem Martins reproduz a mesma caracterização encontrada nos documentos históricos e iconográficos sobre a colonização brasileira.

Já a personagem Iracema é descaracterizada culturalmente e passa a ser apresentada sob a ótica eurocêntrica, num papel estereotipado de "esposa e companheira fiel ao marido", ou seja, Iracema nega suas tradições transgredindo as leis de sua tribo para deitar-se com Martins; fica contra seu irmão Caubé para defender seu marido português; hospeda-se na tribo inimiga de seu povo acompanhando seu esposo; vê seu marido ir lutar contra seus irmãos de sangue, seus familiares, pois ele luta ao lado dos Potiguaras contra os Tabajaras, etnia à qual pertence. Ainda como modelo de submissão, vê seu irmão Caubé sendo morto pelo grupo ao qual seu esposo pertencia e, ainda assim, permanece ao seu lado.

Esse comportamento atribuído a Iracema não corresponde ao das mulheres indígenas, sendo mais um modelo de mulher construído para agradar a um público específico, que é o espectador de filmes pornôs, cuja aspiração é a de ver uma mulher bonita, submissa e sem personalidade, para que possa exercer seu poder e virilidade sem se sentir ameaçado

Uma outra idealização dessa personagem está na sequência 32, quando Poti e Martins são avisados de que os Tabajaras fizeram aliança com muitos guerreiros brancos para combater a nação Potiguara, à qual pertence Poti. Martins parte com Poti para combater os Tabajaras, enquanto Iracema espera pelo português. Apesar de saber que seu marido está saindo para combater seu povo, no filme a imagem de Iracema é explorada de uma forma sensual, dormindo e suspirando na rede. A índia é apresentada como totalmente alheia ao conflito que toma conta de seu grupo étnico. A narrativa mostra uma Iracema que

Comun. Inf., v. 5, n. 1/2, p.63-75, jan./dez. 2002 
parece viver num mundo encantado, desvinculado das preocupações que ocupam os seus irmãos de sangue.

Um outro estereótipo recriado no filme em relação aos índios, reforçando-lhes a imagem de selvageria, está no plano 112 da sequência 26. Num cenário de guerra construído para simular um campo de batalha, têm-se várias cabeças de guerreiros mortos sustentadas por longas estacas de madeira. Essa cena de ferocidade remete ao imaginário europeu a respeito da barbárie atribuída aos povos americanos, já representada nas imagens pictóricas da cartografia, da pintura e também da literatura de viagem. De uma maneira descuidada, a narrativa não situa a cena numa perspectiva cultural.

As alternâncias entre céu e inferno, bem e mal aparecem durante toda a diegese do filme, num exagero extremista que distancia a possibilidade de uma representação menos fantasiosa a respeito do universo cultural indígena.

A imagem do colonizador que se apossa do território dos povos conquistados ganha no filme uma nova versão em relação à história nacional. As sequências 26,27, 28, 29 e 30 são locadas à beira-mar, lugar onde os primeiros portugueses aportaram e fincaram a cruz da igreja católica como símbolo da posse da terra descoberta.

Martins, representante português, de maneira simbólica apossa-se da terra indígena e inicia o processo de transfiguração étnica dos povos autóctones com o consentimento de Iracema. Juntos, na sequência 28 , eles constróem uma cabana de palha na praia, sua casa. A "casa" simboliza ainda uma relação identitária inicial com aquele espaço e pode ser entendida, a princípio, como uma forma alegórica de apropriação de um território, ou seja, a conquista, a posse da terra indígena pelo português.

A linguagem romântica do filme vem esconder e alterar os dados históricos que dão conta dos massacres, lutas e estupros contra as mulheres índias no processo de miscigenação ( RIBEIRO,1982). Nos planos 115, 116 e 117, da seqüência 30, Iracema conta a Martins que ele será pai. Martins se ajoelha e beija a barriga de Iracema. A figura de um fruto comum, oriundo de duas culturas distintas e estranhas uma à outra, sugere a idéia de encontro sem conflitos ou, ainda, de aceitação da alteridade, respeitada em suas diferenças.

Esse discurso ideológico vem camuflar e inverter a violência dos contatos étnicos no processo colonizador e civilizatório que foi responsável pelas transfigurações étnicas indígenas. Muitos grupos indí-

Comun. Inf., v. 5, n. 1/2, p.63-75, jan./dez. 2002 
genas nem chegaram a experimentar tais relações de aculturação, pois foram praticamente exterminados nos primeiros contatos. O filme ignora o processo de aculturação sofrido pelos povos autóctones, e o que o cineasta coloca no plano 127 é uma situação inversa, onde o aculturado é o europeu português que se deixa “impregnar" pela cultura indígena ao ter o corpo pintado e ornamentado com colares e cocar . A nova pele do colonizador, construída pelo diretor do filme, não esconde sua procedência histórica e passa despercebida apenas ao segmento de público ao qual o filme é dirigido.

Na sequência 34, Iracema, já com seu filho miscigenado, tenta escapar de Irapuã que quer matar o bebê, mas que acaba morto pela picada de uma cobra. Dá-se assim a vitória do "bem", o fruto da colonização portuguesa, sobre o "mal", o índio resistente.

No plano 167, sequência 35, Martins está ao lado de Iracema que, aos poucos, morre e pede para que o português cuide de seu filho e a enterre no pé de um coqueiro, para que quando o vento soprar ela pense que é a voz de Martins entre seus cabelos. Esse tipo de construção discursiva tende, mais uma vez, a naturalizar a imagem do índio e a estabelecer um traço de horizontalidade entre ele e a natureza, representação bem típica das cartas jesuíticas do século XVI.

O plano 167 é uma repetição do primeiro plano. A história indígena, não apenas no cinema, mas também em outros suportes, é narrada pelo branco colonizador, vencedor dos combates contra os índios e único a ter acesso aos meios de comunicação e a suportes de difusão de idéias da sociedade capitalista ocidental. O ponto de vista de Martins é também o ponto de vista do diretor, que trouxe para a tela todo um cabedal de informações falsas e preconceituosas sobre os índios.

O público receptor desses filmes vê realimentados seus padrões estereotipados de comportamento em relação às minorias em questão: índios e mulheres. Esse tipo de cinema encaixa-se nos padrões estipulados pela política cultural do governo da década de 70 , nos quais temas relativos à identidade nacional são apresentados de maneira inofensiva ao sistema, ou seja, ao invés de questionar a política estabelecida, cria discursos que propiciam o reforço à maneira de pensar difundida pela ideologia dominante. É um cinema que serve como porta-voz do governo e distancia-se da categoria de obra de arte, representante das preocupações de seu tempo histórico.

Concluímos, então, que a imagem do índio cinematográfico da década de 70 passa por estereótipos e imagens positivas. Mesmo cine-

Comun. Inf., v. 5, n. 1/2, p.63-75, jan./dez. 2002 
astas engajados, como Nelson Pereira dos Santos, acabam por representar um índio genérico, sem identidade étnica específica. Ao "outro" colonizado coube a imagem criada pelo colonizador.

\section{Abstract}

The objective of this article is to analyze the various ways used by the Brazilian movie directors to represent brazilians Indians in the $70 \mathrm{~s}$. The analyses carried out here use basic concepts of historic-politic data and film analyses.

One of the points that is questioned in this work is how the cultural policy of that period, imposed by the government, has influenced the film makers in their representation of Indians and how stereotypes commes in images creating prejudices or positives images of brazilian Indians.

The representation or the fabrication of the Other is never neutral due to the director's own fantasies, excesses, projections, ideologies and political interests.

Keywords: Brazilian indians, representation, film analyses.

\section{Notas}

1. Essa representação do índio como ser adaptado à função servil vem preencher uma necessidade dos colonizadores da época. Esses estereótipos variaram segundo aquilo que era desejado política ou economicamente pelos grupos religiosos ou pelos desbravadores. Os nativos eram chamados de bárbaros para justificar a escravização que lhes queriam impor, ou de demoníacos, para poder reconhecer a presença dos jesuítas e da imposição da doutrina cristã.

2. Ainda hoje, em grupos indígenas isolados, como no Alto Xingu, é proibido o casamento de indígenas com brancos, visando a proteção e continuidade cultural do grupo.

\section{Referências}

ALEGRE, M.S. Imagens e representação do índio no séc.XIX. In: GRUPIONI (Org.). Índios no Brasil. São Paulo: Ed. Global, 2000.

ARANTES, A. A. A guerra dos lugares: sobre fronteiras simbólicas e liminaridades do espaço. Revista do Patrimônio Histórico e Artístico Naciona, São Paulo, 1994.

RAMINELLI, R. Imagens da colonização. São Paulo: Jorge Zahar, 1996.

RIBEIRO, D. Os índios e a civilização. Petrópolis: Vozes, 1982.

STAM, R.; SHOHAT, E. Estereótipo, realismo e representação racial. Revista Imagem, Campinas, 1992.

Comun. Inf., v. 5, n. 1/2, p.63-75, jan./dez. 2002 